\title{
Learning The Ropes: An Introductory Tax Return Case
}

Kevin E. Flynn, West Chester University of Pennsylvania, USA

Lori R. Fuller, West Chester University of Pennsylvania, USA

Peter Oehlers, West Chester University of Pennsylvania, USA

\begin{abstract}
In extant literature, there are few tax return cases appearing in journals. We present a complex case using a realistic scenario that is designed to be an introductory tax return assignment used in an individual federal income taxation course. The case is designed to teach students how to manually prepare a federal income tax return using the actual forms and schedules prepared by the Internal Revenue Service (IRS). This case is timely for two reasons. 1) Often tax return assignments in textbooks involve concepts that a student has yet to learn. For example, a textbook assignment often includes itemized deductions and credits, even though these topics are typically taught towards the end of an individual tax course. 2) In addition, with the availability of information on the internet, students have greater access to solutions to textbook assignments. This case comprehensively examines concepts typically covered in the first three or four chapters of an individual tax text: various types of income, exclusions, personal and dependency exemptions, capital gains and losses, and the standard deduction.
\end{abstract}

Keywords: Tax Case Study; Tax Education; Taxable Income; Interest Income; Dividend Income; Tax Refund; Capital Gain; Capital Loss; and Other Income

\section{INTRODUCTION}

2 teach federal income taxation at a public university in the Mid-Atlantic region. As part of the
accounting curriculum, students are required to take two federal income taxation courses.
Traditionally, students in our program have had to complete four-five assignments involving the preparation of federal individual income tax returns using the actual forms prepared by the Internal Revenue Service. The assigned problems typically were taken from the textbook. During recent years, some students turned in assignments that were word-for-word the same as the solution that appeared in the Solutions Manual. When the verbiage in a student's assignment is the same as the Solutions Manual, this is a red flag. During the 2008-2009 academic year, the solution that appeared in the Solutions Manual for one of the assigned problems was wrong. Some of the students turned in their assignments that included the incorrect information exactly as it appeared in the Solutions Manual. When confronted, all the students admitted that they simply copied the solution from the Solutions Manual that they had obtained using the internet.

Academic dishonesty is more prevalent in collegiate classrooms and has received more attention in recent years by researchers, administrators and the media. According to a recent study performed by the Center for Academic Integrity, more than 75 percent of college students admitted to engaging in some form of cheating (Smith, Davy \& Rosenberg, 2009). According to a presenter at the 2009 American Accounting Association Annual Meeting, most students now have the Solutions Manual in every course they take. A quick search on the internet is all that is required to find the Solutions Manual for nearly every textbook.

In addition, tax return assignments in tax textbooks typically include concepts not yet learned (i.e., itemized deductions on a first or second tax return assignment). Or, tax return assignments include concepts previously learned that should not appear on a third tax return assignment to avoid redundancy (i.e., various forms of income and deductions for adjusted gross income). To be effective, a first tax return assignment should focus only on the concepts learned in the early chapters of the text. 
To address these concerns, we developed our own tax return assignments in the summer of 2009. The case in this paper was first used during the summer of 2009. It was tested in one federal income taxation class during the summer of 2009; refined and tested again in four federal income tax classes during the fall 2009 semester; finally, we further refined and tested for the final time in three classes during the spring 2010 semester.

Our assignment has received positive feedback from students. It challenges them without overwhelming them. Plus, it provides students with valuable experience learning how concepts learned in the classroom appear on IRS forms and schedules. In addition, the case teaches students what reference sources are available to them, what information appears in those sources, and how to use them. Students are forced to learn these lessons because they are unable to simply copy the solution from a Solutions Manual. The remaining sections of this paper explain the learning objectives, provide the actual case, include teaching notes (provided in Appendix A) that offer additional explanations to clarify issues, and include the solution in Appendix B. Finally, as noted in Appendix C, a pdf file is available that shows the actual tax return that should be prepared by the students.

\section{LEARNING OBJECTIVES}

This case is designed to be an introductory tax return assignment that covers the concepts generally taught in the first three or four chapters in an individual federal income taxation text, and it is designed to be completed manually by the students. By manually preparing a return, students can visualize how textbook concepts appear on forms and schedules in an actual tax return; perform computations that are typically performed by tax software programs; and learn how the forms, schedules and supporting documentation relate to each other. This case includes reporting various types of income, personal and dependency exemptions, capital gains and losses, and the standard deduction. In addition, the case provides various forms of cash receipts that are excluded from income. Upon completion of this case, a student understands how to:

1. Identify and handle multiple dependents, including both qualifying children and qualifying relatives.

2. Properly prepare an attached schedule to the Form 1040 when the taxpayer has too many dependents to fit on page 1 of the Form 1040.

3. Perform the personal and dependency exemption phase-out calculation when adjusted gross income (AGI) exceeds the statutory threshold amount.

4. Include interest income, both taxable interest and tax-exempt interest, on both the Form 1040 and Schedule B.

5. Include dividend income, both qualified dividends and unqualified dividends, on both the Form 1040 and Schedule B.

6. Report capital gains and losses. Included in this objective is how to complete both Schedule D and Schedule D-1.

7. Account for personal use property gains and losses.

8. Account for life insurance proceeds received and an inheritance received, both of which are excluded from income taxation.

9. Report compensation received for injuries, including both taxable (punitive damages) and nontaxable (personal injury damages) awards.

10. Apply the tax benefit rule to account for a state income tax refund received in the current year.

11. Report a prize received.

12. Report gambling income.

13. Properly complete and attach a schedule to the back of the return to report other income.

14. Compute and report the standard deduction. Included in this computation is an additional standard deduction (ASD) from the real estate tax payments. The ASD requires the inclusion of Schedule L.

15. Compute the tax liability when the long-term capital gain (LTCG) alternative tax is used.

16. Apply prior year's refund to current year's tax prepayments.

17. Account for making an estimated federal income tax payment made during the year.

18. Report the $\$ 3$ contribution to the presidential election campaign.

19. Report the deposit of a refund directly into a bank account.

20. Include the daytime phone number on page 2 of the Form 1040. 


\section{THE CASE}

Bernard M. Bergermeister (age 53) lives at 53124 Cincinnati Drive, Chillicothe, OH 45601. Bernard lost his late wife, Betty, in December 2007 as a result of a commuter airplane crash. Bernard and Betty were married for 25 years before her untimely death. Each year that they were married, Bernard and Betty filed a joint tax return. Bernard is employed as a carpenter by Reliable Services, 696 Atkinson Road, Chillicothe, OH 45601. In 2009, his gross salary was $\$ 89,000$. Bernard wants to contribute $\$ 3$ to the presidential election campaign fund. His daytime phone number is 740-835-1436. If Bernard is owed a refund, he wants it deposited directly into his checking account. The checking account number is 9638527410 , and the bank's routing number is 031000011.

Bernard has the following children who live at home: Barry (age 23), Brianna (age 22), Bart (age 20), and twins Barclay and Bonnie (age 18).

- $\quad$ Barry -- Graduated from college 2 years ago at the age of 21 . He is living at home while he continues to seek full-time employment. He earned \$3,200 working part-time during 2009.

- Brianna -- Is a full-time graduate student who pays her own tuition. She earned \$5,000 working during the summer of 2009.

- $\quad$ Bart -- Does not attend school and earned $\$ 9,000$ during 2009 working various jobs.

- $\quad$ Barclay - Attends high school full-time. During the summer, he earned $\$ 4,900$ working in a factory.

- $\quad$ Bonnie - Attends high school full-time. During the summer, she earned \$1,900 working as a waitress at a local restaurant.

In addition to his own 5 children, Bernard also has a nephew, Barack Barrimore (age 19), who lived with him throughout 2009. Barack does not attend school and earned \$3,400 during 2009 working part-time. Also residing with Bernard is Betty's widowed mother, Birdie Bleecker (age 75). Bernard provides over half the support of all individuals living with him. Birdie receives Social Security benefits of $\$ 8,000$, but has no other income.

Bernard's cash receipts for 2009 include the following:

Interest -

City of Columbus bonds $\$ 5,600$

General Motors bonds $\quad 2,300$

Canton National Bank certificate of deposit $\quad \underline{4,200}$

Dividends -

ABC Corp. stock (unqualified) $\$ 3,210$

DEF Corp. stock (qualified) $\quad 6,300$

GHI Corp. stock (qualified) $\quad \underline{4,300}$

Life insurance proceeds

13,810

175,000

Inheritance

105,000

Airline settlement -

Punitive damages $\$ 150,000$

Personal injuries $\quad \underline{130,000}$

The insurance proceeds were paid to Bernard because he was the beneficiary of a policy he held on Betty's life. The inheritance represents what was left of Betty's estate after all debts and administration expenses were paid. Because Bernard believed that Betty's death was caused by the airline's negligence, he threatened to file a lawsuit against the airline. In a settlement with the airline's insurance carrier, Bernard signed a release of all claims in return for the $\$ 280,000$ payment. The personal injury portion of the payment was designated as being for the "personal injuries suffered by Betty Bergermeister." Bernard did not hire an attorney, but rather represented himself in this process. 
Bernard received a $\$ 1,200$ income tax refund from the state of Ohio on 5/29/09. On his 2008 Federal income tax return, he reported total itemized deductions of $\$ 11,700$, which included a $\$ 3,200$ state income tax deduction. During 2008, Bernard's real property taxes on his personal residence were paid monthly out of a trust fund that was established by Betty's sister at the time of Betty's death. The trust fund expired 8/31/09 and Bernard began paying his own property taxes on 9/1/09.

Bernard has always been an avid weightlifter. During 2009, he entered a bodybuilding contest. To his surprise, he won a prize of $\$ 7,000$. In addition, during 2009 , Bernard bought a $\$ 6$ raffle ticket and won a laptop computer valued at $\$ 1,500$. Finally, Bernard won $\$ 1,600$ playing the lottery. The cost of the lottery ticket was $\$ 5$.

Bernard's cash payments for 2009 include real property tax paid on Bernard's personal residence for the period 9/1/09 - 12/31/09 totaling \$900. In addition, other payments that would qualify as itemized deductions such as home mortgage loan interest, state and local income taxes paid, and charitable contributions totaled $\$ 10,300$. Bernard made no other payments in 2009 that qualified as itemized deductions.

Bernard bought a used mini-van that he used for personal purposes for $\$ 4,200$ on 3/15/09. He purchased the vehicle from a friend who needed the cash. On 9/12/09, he sold the vehicle to someone he did not know for $\$ 4,800$. In addition, on $10 / 11 / 09$, Bernard sold his Italian sports car for $\$ 25,000$. He had originally purchased the car on $10 / 16 / 06$ for $\$ 40,000$, and used it exclusively for personal purposes.

Bernard sold the following securities during 2009:

\begin{tabular}{|c|c|c|c|c|c|}
\hline Corporation & \# of Shares & Date Sold & $\begin{array}{c}\text { Date } \\
\text { Acquired }\end{array}$ & $\begin{array}{c}\text { Sales } \\
\text { Price } \\
\text { Per Share }\end{array}$ & $\begin{array}{l}\text { Purchase } \\
\text { Price } \\
\text { Per Share }\end{array}$ \\
\hline Orange Corp. & 20 & $04 / 12 / 09$ & $08 / 22 / 08$ & $\$ 25$ & $\$ 30$ \\
\hline Lime Corp. & 30 & 05/13/09 & 09/23/08 & $\$ 30$ & $\$ 26$ \\
\hline Lemon Corp. & 40 & $06 / 14 / 09$ & $10 / 24 / 08$ & $\$ 35$ & $\$ 22$ \\
\hline Apple Corp. & 50 & 07/15/09 & $11 / 25 / 08$ & $\$ 40$ & $\$ 65$ \\
\hline Peach Corp. & 60 & 08/16/09 & $12 / 26 / 08$ & $\$ 45$ & $\$ 60$ \\
\hline Pear Corp. & 70 & 09/17/09 & $01 / 27 / 09$ & $\$ 50$ & $\$ 62$ \\
\hline Nectarine Corp. & 80 & $10 / 18 / 09$ & $02 / 28 / 09$ & $\$ 55$ & $\$ 52$ \\
\hline
\end{tabular}

Relevant social security numbers are as follows:

Bernard Bergermeister

Betty Bergermeister

Barry Bergermeister

Brianna Bergermeister

Bart Bergermeister

Barclay Bergermeister

Bonnie Bergermeister

Barack Barrimore

Birdie Bleecker
789-16-4576

689-17-3465

589-18-2354

489-19-1243

389-12-0132

289-13-6798

189-14-5687

089-15-5688

889-16-5689

The total amount of Bernard's federal income taxes withheld by his employer in 2009 totaled $\$ 14,625$. Bernard's employer also withheld appropriate amounts for payroll taxes. In addition, Bernard applied his 2008 refund of federal income taxes of $\$ 575$ toward his 2009 tax liability. Finally, after receiving the airline settlement, Bernard made an estimated federal income tax payment of $\$ 38,000$ in 2009.

\section{TAX COMPUTATION}

Ignoring the alternative minimum tax, prepare Bernard's federal income tax return for 2009. The return should include the following forms and schedules: 
- $\quad$ Form 1040

- $\quad$ Schedules B, D, D-1 and L

\section{Hints:}

1. If the information requested by the IRS does not fit in the allotted space on a tax form, include the information on a schedule attached to the back of the return. Be sure to reference the attached schedule on the form by writing something like "See Attached Schedule".

2. Including Schedule A with the return is only necessary if you choose to itemize deductions. If you choose to use the standard deduction, it is not necessary to include Schedule A.

3. Ordinary qualified dividends are included on both lines $9 \mathrm{a}$ and $9 \mathrm{~b}$ on page 1 of the Form 1040. Unqualified dividends are only included on line $9 \mathrm{a}$.

\section{LIMITATIONS AND CONCLUSIONS}

As to be expected, limitations exist and should be recognized. If the assignments are returned to students, then the potential exists for students to copy the prior semester's solution. However, this obstacle can be overcome by changing the amounts, revising the facts, and adding/subtracting a couple of concepts each semester. In addition, the IRS forms change each year. Plus, there are inflation adjustments, rate changes, and other minor revisions to the tax law most years. However, the concepts rarely change. The assignment presented in this paper should be able to be used as a template for many years. Tax instructors will find the assignment in this paper to be an effective alternative to using an assigned problem from a tax text.

\section{AUTHOR INFORMATION}

Kevin E. Flynn, $\mathrm{PhD}, \mathrm{CPA}$, is an associate professor at West Chester University. He worked for seven years in public accounting in the Philadelphia offices of Ernst \& Young and PriceWaterhouseCoopers. Subsequently, Kevin worked in industry as a financial reporting manager, assistant controller, and controller before entering academia full time in the fall of 1993. His PhD in Accounting was earned at Drexel University. He primarily teaches individual and business federal income taxation. His research interests involve individual income taxation.

Lori R. Fuller, $\mathrm{PhD}, \mathrm{CPA}$, is an associate professor at West Chester University. Her $\mathrm{PhD}$ in Accounting was earned at Arizona State University. Her research interests lie in auditing and forensic accounting; whereas her teaching interests are auditing and accounting systems at both the graduate and undergraduate levels. She has published in BRIA, the Journal of Forensic Accounting, Strategic Finance and Management Accounting Quarterly. One of her recent publications won a national award from the Institute of Management Accounting (IMA) for its contribution to the literature. On a personal level, Lori spends time with her spouse and six four-legged children.

Peter Oehlers, DBA, CPA, CMA, is currently an Associate Professor of Accounting at West Chester University. His research has been published in Issues in Innovation, The Journal of Financial Services Professionals and Strategic Finance. He has twice received the Distinguished Undergraduate Teaching Award at Widener University as well as the West Chester University Inter-fraternity council outstanding professor award. He serves on the editorial board of Issues in Innovation and Associate Editor of the Journal of Mentored Management Accounting Research. His research interests include environment accounting, auditing for identity theft, and ethics in accounting information systems.

\section{REFERENCES}

1. Smith, K., Davy, J., \& Rosenberg, D. 2009. The Influence of Motivation and Attitude on Cheating Behavior Among Accounting Majors. Unpublished Working Paper. 


\section{APPENDIX A}

\section{Teaching Notes}

1. This case was tested in eight different introductory federal income tax classes: one class in the summer of 2009 , four classes in the fall of 2009, and three classes in the winter of 2010. By testing the case with actual students, we learned that it is important to give the three hints that are stated in the "Tax Computation" page.

Hint \#1 - The first hint teaches students how to attach data to the back of a return. This concept is not explained in a textbook and is not always easily found in the IRS instructions.

Hint \#2 - The second hint is necessary because many students preparing a tax return for the first time will complete Schedule A even though it is not necessary since the standard deduction is used.

Hint \#3 - Without this hint, students include only unqualified dividends on line 9a, instead of both unqualified and qualified dividends on line 9a. This compliance requirement is not typically explained in a tax text and is not well explained in the IRS instructions.

2. Students often get confused and frustrated when they have to determine which forms and schedules to include with the return, and have a hard time getting started. Stating on the "Tax Computation" page which forms and schedules must be included with the return gives students enough guidance to keep them focused and learning, without giving them too much information.

3. The taxpayer, Bernard, threatens to file a lawsuit. It is important to have Bernard represent himself so that paying attorneys' fees is not an issue, since this concept is generally not covered in the first four chapters of a tax text.

4. Bernard receives a state income tax refund in the current year. In order to determine the amount of the refund that is included in 2009 income, students must apply the tax benefit rule. The tax benefit rule states that the taxpayer must include the refund in income to the extent that a benefit was previously derived. To determine how much benefit was previously derived, prior year's (2008) total itemized deductions must be compared to the total standard deduction. Beginning in 2008, Congress began allowing taxpayers to increase their standard deduction by the amount of real property taxes paid, up to $\$ 500$ ( $\$ 1,000$ for married filing jointly). In early versions of the case, students struggled to apply both this new standard deduction rule and the tax benefit rule at the same time. Therefore, we decided to have 2008 real property taxes paid from a trust fund so that students could focus only on the tax benefit rule in this computation. However, in 2009 , Bernard begins paying his own real property taxes so that students can address the concept of adding real property taxes paid to the amount of the standard deduction.

5. We want students to perform the personal and dependency phaseout computation, which is a concept generally learned in the first couple of chapters of a tax text. However, in order to have the phaseout be applicable, we had to construct a case where adjusted gross income was high enough to cause the alternative minimum tax (AMT) to apply. However, the AMT is an advanced concept that students generally learn later in a tax course, if at all. Therefore, for this case, we have the students ignore the AMT so that it is not an issue.

6. This case includes qualified dividend income that is taxed at long-term capital gain (LTCG) alternative rates. When computing the taxpayer's tax liability, the actual tax return, Form 1040, does not have a separate line for computing the liability on income taxed at LTCG alternative rates. The Form 1040 instruction booklet provides a table that students can use to walk through the calculation. However, the first couple of times this case was tested with students, many students missed this computation. Therefore, during the winter 2010 semester, we chose to emphasize this concept in class. In the future, an instructor using this case could choose to emphasize the concept in class, or provide students with a "hint", just like we provide the hints on our "tax computation" page. 
7. This case involves writing multiple social security numbers when completing the section for dependent exemptions. Also, multiple dates that are listed on Schedule D since the case involves multiple sales of stock. In order to effectively grade a large number of tax return assignments, we show a pattern when assigning social security numbers and dates to this case. When the numbers are in a pattern, it makes it easier to spot errors when the instructor has to review a lot of assignments.

8. The "Making Work Pay" credit that Congress instituted for 2009 (and 2010 also) is not an issue because the adjusted gross income is over the $\$ 190,000$ limit.

9. Finally, this case is designed for the students to complete manually, which we feel is the only effective way to teach students how concepts appear in a return. Anecdotally, we have learned that when students complete an assignment using tax software, the students simply learn how to type information into an input screen, but do not effectively learn how concepts appear on the forms and schedules of a return. Students, both current and former, who work in the tax departments of CPA firms, tell us that their development was greatly enhanced due to the fact that they prepared their tax return assignments manually, as this is how they learned to compute amounts that appear in a return, and how the forms and schedules relate to each other. 


\section{APPENDIX B}

\section{Solution}

Income

Salary

89,000

Interest Income -

City of Columbus Bonds - Excluded

$\$$

General Motors Bonds

0

Farmer's Bank CD

2,300

$\underline{4,200}$

Dividend Income -

$$
\begin{aligned}
& \mathrm{ABC} \text { stock (unqualified) } \\
& \mathrm{DEF} \text { stock (qualified) }
\end{aligned}
$$

$\$ 3,210$

6,300

$\underline{4,300}$

State Income Tax Refund (Note 1)

Punitive Damages - Airline Settlement

Bodybuilding Contest Prize

$\$ 150,000$

7,000

Laptop Computer Prize

1,500

Lottery Winnings

Total Other Income

1,600

Total Income (Note 2)

Less: Deductions For AGI

Net Capital Loss (Note 3)

Adjusted Gross Income (AGI)

Less:

Standard Deduction (Note 4)

Personal and Dependency Exemption (Note 5)

Taxable Income

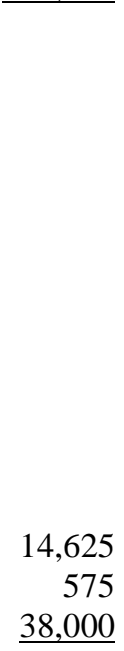

$\underline{38,000}$

$(1,610)$

$\$ 268,600$

$(11,900)$

$(24,187)$

$\$ 232,513$

Tax Liability (Note 6)

$\$$

52,642

Less:

Withholdings

\$ 14,625

Overpayment of 2008 taxes

Estimated payment made during 2009

Net Tax Payable (or Refund Due)

53,200

(\$558) 


\section{NOTES}

(1) Must recognize income to the extent that a benefit was previously derived.

Total Itemized Deductions in the prior year

Less: Total Standard Deduction in the prior year

Benefit Received in the prior year
$\$ 11,700$

$(10,900)$

$\$ \quad 800$

$\$ 175,000$

105,000

130,000

(2) The following are excluded from gross income:

Life insurance proceeds

Inheritance

Airline settlement - Personal injuries

Since Bernard acted as his own counsel and thus did not pay any attorney's fees, the fees do not need to be accounted for.

(3)

Corporation/Item

Stock Sales:

Orange Corp.

Lime Corp.

Lemon Corp.

Apple Corp.

Peach Corp.

Pear Corp.

Nectarine Corp.

Net STCL from Stock Sales

Sales of Personal Use Assets:

Mini-van

Sports car

Overall Net Capital Gain (Loss)

* Personal use losses are not deductible.

(4) Itemized deductions are as follows:

Real Property Tax on personal residence

$\underline{\text { Proceeds }}$

$\$ 500$

900

1,400

2,000

2,700

3,500

4,400

4,800

25,000
Basis $\quad$ Gain (Loss)

$\$ 600 \$(100)$

$780 \quad 120$

$880 \quad 520$

$3,250 \quad(1,250)$

$3,600 \quad(900)$

$4,340 \quad(840)$

$4,160 \quad 240$

$\$ \quad(2,210)$

4,200

40,000

$\$ \quad \begin{array}{r}600 \\ \% \\ \hline\end{array}$

Other Itemized Deductions

Total Itemized Deductions

Bernard's filing status is surviving spouse. As such, his standard deduction is computed as follows:

Basic Standard Deduction

$\$ 11,400$

Add Real Estate Taxes Paid --

Lesser of: Tax Paid or $\$ 500$

Total Standard Deduction

$\$ \frac{500}{11,900}$

Therefore, Bernard will choose to use the standard deduction since the amount is greater than the total itemized deduction amount.

(5) Personal and Dependency Exemption Summary:

Bernard - Personal Exemption

$\$ 3,650$

Barry - Qualifying Relative

He meets the Gross Income Test.

Brianna - Qualifying Child

She meets the Age Test because she is a full-time student less than age 24 . 
Bart - Not a dependent

Not a Qualifying Child due to the Age Test.

Not a Qualifying Relative due to the Gross Income Test.

Barclay - Qualifying Child

Gross Income Test is not applicable for QC classification $\quad 3,650$

Bonnie - Qualifying Child

3,650

3,650

Barack Barrimore - Qualifying Relative

3,650

Birdie Bleecker - Qualifying Relative

$\$ \underline{25,550}$

Exemption Phaseout Computation

Exemption Amount $(7 \times \$ 3,650)$

$\$ 25,550$

Step 1:

Adjusted Gross Income

$\$ 268,600$

Phase-Out Threshold

$(\underline{250,200)}$

Excess Amount

$\$ \quad 18,400$

Step 2:

$\$ 18,400 / \$ 2,500$ (rounded up)

Step 3:

Step 4:

Unadjusted Phase-Out Amount [\$25,550 x $16 \%]$

$=\underline{\$ 4,088}$

Step 5:

Adjusted Phase-Out Amount [\$4,088 x 1/3]

$(\underline{1,363})$

Deduction for Personal and Dependency Exemptions

$\$ \underline{24,187}$

(6) Bernard qualifies as a Surviving Spouse:

- His wife died during the 2 tax years preceding the current year; and

- Bernard maintains a household for a dependent child.

Therefore, Bernard uses the Married Filing Jointly rate schedule.

Taxable Income

$\$ 232,513$

Less: Qualified Dividends [ $\$ 6,300+\$ 4,300]$

$(10,600)$

Amount taxed at Ordinary Income (OI) Rates

$\$ \underline{221,913}$

Tax on Ordinary Income using the Tax Rate Schedule

$[\$ 46,741.50+.33(\$ 221,913-\$ 208,850)]$

$\$ 51,052$

Tax on Qualified Dividends [ $\$ 10,600$ x 15\%]

Tax Liability

$\$ \quad \frac{1,590}{52,642}$ 


\section{APPENDIX C}

Tax Return

For a copy of a pdf file that contains the tax return that goes with this case, please contact the author. 


\section{NOTES}

